\section{David Anderson-Berry Prize (1961)}

A David Anderson-Berry Medal, together with a sum of money amounting to not less than $£ 100$, will be awarded in 1961 by the Council of the Royal Society of Edinburgh. The Prize will be awarded for recent work on the effects of X-rays and other forms of radiation on living tissues. Published work will be taken into consideration if submitted to the Society with the application. In addition to direct application for the Prize, proposals may be made on behalf of others. Applications and proposals should be sent to the General Secretary, Royal Society of Edinburgh, 22/24 George Street, Edinburgh 2, not later than March 31, 1961.

\section{University News :}

Edinburgh

THe title of Research Fellow in the Department of Animal Genetics has been conferred on Dr. J. L. Sirlin; Mr. D. M. Weir has been appointed lecturer in the Department of Bacteriology, and Dr. R. G. S. Leask has been appointed lecturer in the Department of Clinical Chemistry.

Glasgow

Dr. J. H. Renwick has been appointed senior lecturer in human genetics. The following have been appointed lecturers: R. W. P. Drever, W. Jack and E. W. Laing (experimental and theoretical physies) ; T. M. Hoodless and W. Parker (chemistry); J. S. Keates (geography); and D. J. Simms (mathematics). G. L. le Bouvier has boen appointed to a research fellowship in gonetics, and 1 . Hughes and D. A. R. Wallace in mathematics. A. L. Porte has been appointed an Imperial Chemical Industries Fellow in chemistry.

The second Fleck Lecture is to be given on February 22, 1961, by Dr. John Paul (biochemistry).

For the present session, 396 new studonts (286 men and 110 women) have been admitted to the Science Departments, compared with 392 in 1959. The total of matriculated students in the University as a whole now stands at 6,600 , compared with 6,566 in 1959 .

London

DR. D. G. Evans, director of the Department of Biological Standards in the National Institute for Medical Research, has been appointed to the University chair of bacteriology and immunology tenable at the London School of Hygiene and Tropical Medicine. Dr. J. D. N. Hill, senior lecturer in the Institute of Psychiatry and lecturer in psychological medicine at King's College Hospital Medical School, has been appointed to the University chair of psychiatry tenable at Middlesex Hospital Medical School.

\section{Announcements}

Dr. S. M. Partridae has been appointed hoad of the Eggs and Poultry Department of the Low Temperature Research Station, Cambridge, following the death of Dr. J. Brooks (see Nature, 188, 451; 1960). Dr. Partridge will also continue to be in charge of the Protein and Ion-Exchange Department.

Dr. H. F. DADSweLc has been appointed chief of the Division of Forest Products of the Commonwealth Scientific and Industrial Research Organization, Australia. Ho succeods Mr. S. A. Clarko, who retired in August. Dr. Dadswell, who has been with the Division since its inception, was previously assistant chief and officer-in-charge of the Division's Wood and Fibro Structure Soction.
DR. J. R. FURlong, scientifie adviser since 1953 to the Pyrethrum Board of Kenya, has retired and will take charge of the London office of the African Pyrethrum Technical Information Centre in succession to Dr. T. F. West, who has been appointed editor of Chemistry and Industry, the journal of the Society of Chemical Industry. Dr. Furlong was chairman of the Consultative Committee on Insecticides of Vegetable Origin at the Imperial Institute, and in 1946 he took a leading part in the survey of methods for the analysis of pyrethrum, which resulted in the world-wide collaborative scheme carried out in 1948-49.

D. Van Nostrand Co., Ltd., regret to state that there are mistakes in titles of authors mentioned in their advertisement of the "International Dictionary of Applied Mathematics", published in Nature of December 10 (p. i of Supplement); thus Prof. B. H. Flowers, author of the section on "Nuclear Science", is now professor of theoretical physics in the University of Manchester ; the section on "Aerodynamics and Hydrodynamics" is by Prof. W. A. Mair and Dr. R. S. Scorer, and that on "Probability and Statistics" by Prof. M. G. Kendall.

THE Faraday Society is holding an informal dis. cussion on "Mechanisms of the Gas-phase Reactions of the Halogens and their Compounds" in the Chemistry Department, University College, Cardiff, on March 28,-1961. Further information can be obtained from Dr. J. H. Thomas, Chemistry Department, University College, Cathays Park, Cardiff.

A symposium on "Molecular Structure and Spectroscopy" is to be held in the Department of Physics and Astronomy, Ohio Stato University, during June 12-16, 1961. Further information can be obtained from Prof. R. A. Oetjen, Department of Thysics and Astronomy, Ohio State University, Columbus 10, Ohio.

THE first international congress on "Metallic Corrosion" is to be held at the Imperial College of Science and Technology, South Kensington, London, S.W.7, during April 10-15, 1961. Further information can be obtained from the Honorary Secretary, First International Congress on Metallic Corrosion, 14 Belgrave Square, London, S.W.1.

THE Mather Lecture for 1961 will be given in conjunction with the annual general meeting of the Textile Institute to be held on April 20. The Lecture will be given by Dr. A. Clow, senior producer of the Science Unit of the British Broadcasting Corporation, and his subject will be "Chemistry in Scotland and its Pioneer Contributions to Textile Technology". Further information can be obtained from the Secretary, Textile Institute, 10 Blackfriars Street, Manchester 3.

AskFD for a statement on the Low Temperature Research Station, Cambridge, Mr. C. Soames, the Minister of Agriculture, Fisheries and Food, as representing the Minister for Science, in a written answer on November 24 stated that the building occupied by the Station was held on a 10-year loase from the University. The lease expired in 1966 and the University had given notice that it could not renew the lease as the space is required for othor purposes. The Agricultural Rosearch Council was considering the future of the work being carried on at the Station. 